ISSN 1392-3196 / e-ISSN 2335-8947

Zemdirbyste-Agriculture, vol. 106, No. 1 (2019), p. 65-72

DOI 10.13080/z-a.2019.106.009

\title{
Influence of light modification on postharvest butter lettuce quality: differences between external and internal leaves
}

\author{
Jasna MASTILOVIĆ ${ }^{1}$, Žarko KEVREŠAN ${ }^{1}$, Aleksandra JAKŠIĆ ${ }^{1}$, Ivan MILOVANOVIĆ ${ }^{1}$, \\ Radmila TRAJKOVIĆ ${ }^{2}$, Milica STANKOVIĆ ${ }^{2}$, Lidija MILENKOVIĆ ${ }^{3}$, Zoran S. ILIĆ ${ }^{3}$ \\ ${ }^{1}$ Institute of Food Technology, University of Novi Sad \\ Bulevar Cara Lazara 1, 21000 Novi Sad, Serbia \\ ${ }^{2}$ Faculty of Natural Sciences and Mathematics, University of Priština \\ Lole Ribara 29, 38220 Kosovska Mitrovica, Serbia \\ ${ }^{3}$ Faculty of Agriculture, University of Priština \\ Kopaonička bb, 38219 Lešak, Serbia \\ E-mail: zorans.ilic@pr.ac.rs
}

\begin{abstract}
The aim of the study was to investigate the influence of coloured shade-nets (pearl, blue, red and black with $50 \%$ shade index) in comparison to open field (non-shaded plants) on quality traits of different butter lettuce (Lactuca sativa L. var. capitata) cultivar 'Tizian' leaves (external and internal) from summer production at harvest and during storage. Leaves from non-shaded plants were characterized by higher content of soluble sugars and acids in comparison to shaded plants. At harvest, significantly higher content of chlorophyll, total phenols and micro elements was recorded in external than in internal leaves. Internal leaves had higher content of soluble sugars (glucose, fructose and sucrose) and higher organic acids (malic and succinic) content than external (light exposed) leaves, but citric acid was present only in external leaves. Total phenol content in leaves exposed to the light was by $55-85 \%$ higher than in shaded lettuce. Total sugar content and total acid content in lettuce leaves increased during storage, more intensively in non-shaded than in shaded leaves. Chlorophyll content changes in lettuce occurred predominantly in outer leaves of lettuce, while in inner leaves no significant changes were noted.
\end{abstract}

Key words: colour nets, Lactuca sativa, leaf position, loss, quality, storage.

\section{Introduction}

Lettuce (Lactuca sativa L.) is a popular leafy vegetable and plays an important role in diet and nutrition, traditionally cultivated under open field on soil (Ilić et al., 2017 a) or in the greenhouse by hydroponics technique (Mampholo et al., 2016). Lettuce is used for fresh consumption in fast food and prepared salads without any restriction for daily consumption (Kosma et al., 2013). Consumption of lettuce contributes to the human body nutritional balance of protein, fatty acids, carbohydrate and dietary fibre. Lettuce promotes antiobesity activity because it is low in calories. Lettuce is low in sodium content and it is fat-free and primarily consists of water (Kim et al., 2016). The composition of bioactive compounds in lettuce depends on many preharvest factors such as genotype and environmental conditions - light, temperature (Ilić et al., 2017 a), growing season (Kapoulas et al., 2017) and agronomic practices (Rouphael et al., 2012). However, bioactive compounds content and composition in lettuce also depend of the tissue type and the outer or inner position of the leaves (Degl'Innoocenti et al., 2008), harvest time (Kapoulas et al., 2017) and storage conditions (Cantwell, Suslow, 2002).

The global climate change is leading to increases in biotic and abiotic stresses that can cause lower crop production. Therefore, more efficient crop management is demanded particularly having in mind the demands for supply of crops out of the regular growing season. Production of cool-season vegetables like lettuce during the summer months represents a challenge for growers (Ilić et al., 2017 a). Lettuce seems to be a model crop well studied for light quality and temperature response. The colour, texture, flavour, taste and other attributes are important parameters for successful marketing of lettuce, and these factors determine the market price and the consumer preference. Many of these quality indicators are largely influenced by mentioned abiotic and biotic factors.

Please use the following format when citing the article:

Mastilović J., Kevrešan Ž., Jakšić A., Milovanović I., Trajkovic R., Stanković M., Milenković L., Ilić Z. S. 2019. Influence of light modification on postharvest butter lettuce quality: differences between external and internal leaves. Zemdirbyste-Agriculture, 106 (1): 65-72. DOI 10.13080/z-a.2019.106.009 
Besides temperature, lettuce production also depends on light properties, light quality and light intensity (Ilić, Fallik, 2017). Dufault et al. (2009) reported that as planting dates progressed toward warmer temperatures and longer days, lettuce yield and quality were negatively affected. The most efficient method to diminish the negative effects of excessive light could possibly be the use of shade nets because they can modify environmental conditions and manipulate light quality (Demotes-Mainard et al., 2016). Depending on the thread pigmentation and knitting design with different fibres and density used for creation of nets with specific shade indices (Castellano et al., 2008), the photo-selective coloured shade nets provide diverse mixtures of natural, unmodified light and scattered, spectrally modified light (Shahak et al., 2009; Milenković et al., 2012). In addition to light, shade nets can modify environmental variables such as temperature, wind speed, or relative humidity inside the canopy (Arthurs et al., 2013).

Significantly higher total phenol content, total flavonoids content and antioxidant properties were recorded in lettuce plants grown under the pearl shade in comparison to all other nets. It was also shown that application of shade nets influences the retention of sensory qualities such as flavour, texture and appearance as the trait being affected by suboptimal conditions for lettuce growing during the summer period (Ilić et al., 2017 a). The use of colour shade nets creates favourable microclimate and provides physical protection against pest and physical damage (Selahle et al., 2014), physiological disorders (Ilić al., 2012) thereby improving the quality of vegetables (Ilić et al., 2015; 2017 b).

Several studies have demonstrated that leaf position affects leaf composition as well as its metabolic activity (Siomos et al., 2002; Agüero et al., 2008). Besides the differences in chlorophyll content in the cultivars of both lettuce types (romaine 'Parris Island' and leaf type lettuce 'Atraxion'), the inner leaves had the highest content of dry matter and soluble solids, soil acidity $(\mathrm{pH})$ and titratable acidity; the outer leaves had the highest nitrates, while the middle leaves had the highest ascorbic acid, with the exception of plants of the leaf type, in which no significant difference in ascorbic acid relative to leaf position, was observed (Siomos et al., 2002).

Although photo-selective nets have been used to maintain favourable microclimates for growing of lettuce (Shahak et al., 2009), effects of moderate shade with photo-selective nets on lettuce yield and quality are limited. However, very little information is available on how different types of coloured shade netting affect the phytochemical content in fresh produce and the retention of compounds during postharvest storage.

Butter lettuce is among the leafy vegetables that are highly perishable and have a short shelf life as they suffer significant quantitative, qualitative and economic losses along the supply chain. The lettuce can be stored $21-28$ days in $0^{\circ} \mathrm{C}$ with $95 \%$ relative humidity. At $5^{\circ} \mathrm{C}$ a shelf-life of 14 days can be expected as long as no ethylene is in the environment (Cantwell, Suslow, 2002). The wilting process is associated with water loss in lettuce, leading to losses in weight and quality. These losses occur due to metabolic reactions (large surface-area-to-mass ratio) that change product texture and the transpiration rate that minimizes the wilting process, which can be done with increased relatively humidity and decreased temperature in the storage place. The knowledge regarding the effect of leaf age on the quality indices is of fundamental importance for producers because they can take decisions based on degree of development of tissue. By applying mentioned knowledge, producers could use different lettuce leaves for alternative uses for example, for fresh consumption, minimally processed products, etc.

Our hypothesis is that different coloured shade nets will influence the composition of both external and internal leaves of butter lettuce, produced during the summer period, at harvest and also during the postharvest storage.

\section{Materials and methods}

Plant material. Production of a summer cultivar 'Tizian' of butter lettuce (Lactuca sativa L. var. capitata) was conducted during the summer period in 2016 in an experimental net house in South Serbia $\left(21^{\circ} 42^{\prime}\right.$ E, $43^{\circ} 30^{\prime}$ $\mathrm{N}$, altitude $159 \mathrm{~m}$ ). Production was carried out under the red, blue, white and black nets ChromatiNet (Polysack Plastics Industries, Israel) with a shade index of $50 \%$ and in the open field. A randomized block design with three replicates of 40 plants $\left(5 \mathrm{~m}^{2}\right)$ was adopted. Experiments were repeated three times during the summer months (June, July and August).

Lettuce seedlings with four true leaves were transplanted four weeks after sowing with $40 \mathrm{~cm}$ spacing between rows and $30 \mathrm{~cm}$ in a row. Fertilization included regular supplemental feeding drip system and foliar application of NPK of formulation 12:11:24 + ME (Yara Mila Complex). Lettuce heads were harvested 35 days after transplanting.

After harvest, five lettuce heads from each block were randomly selected for preparation of samples for further analysis. After removal of unmarketable leaves, three outer layers of every lettuce head were collected and average samples of leaves exposed to the direct light were formed from the heads from each block. Approximately $100 \mathrm{~g}$ from the middle part of every head were collected and average samples of internal leaves not exposed to the direct light were formed from the heads from each block and frozen until analysis.

Another ten heads from each block were stored in a cooling chamber at $0^{\circ} \mathrm{C}$ and relative humidity $(\mathrm{RH})$ over $95 \%$. Ten and twenty days after harvest, five heads from each block were used for the analysis of changes in lettuce composition during the postharvest period depending on the growing conditions and leaf position in the lettuce head. Sample preparation was conducted according to the previously described procedure.

Prior to analysis, frozen samples were homogenized in a blender and average samples were used for pigment, phenols, flavonoids, sugars and acids content determination. For the analysis, the average samples were formed from the frozen plant material from three harvests.

Chlorophyll content. Pigments were extracted from $0.5 \mathrm{~g}$ of plant material with $20 \mathrm{~mL}$ of acetone and chlorophyll content was determined from the supernatant obtained after centrifugation for 5 minutes at $10.000 \times$ rpm with centrifuge 5804R (Eppendorf, Austria). Chlorophyll $a$ and $b$ content was calculated from the absorbances at 662 and $645 \mathrm{~nm}$ with spectrometer Cintra 303 (GBC Scientific Equipment, Australia) according to the formulas proposed by Costache et al. (2012): 
Chlorophyll $a=11.75 A_{662}-2.35 A_{645}$, Chlorophyll $b=18.61 A_{645}-3.96 A_{662}$.

Mineral profile. For determination of macro and micro elements homogenized samples $(0.5 \mathrm{~g})$ were digested using a microwave oven Ethos 1 (Milestone Srl., Italy) in $7 \mathrm{ml}$ nitric acid $\left(\mathrm{HNO}_{3}\right)$ and $1 \mathrm{ml}$ hydrogen peroxide $\left(\mathrm{H}_{2} \mathrm{O}_{2}\right)$. Digested samples were transferred to $50 \mathrm{ml}$ flasks together with solutions of caesium (Cs) and lanthanum $(\mathrm{La})$. Measurements of each element $(\mathrm{K}, \mathrm{Ca}$, $\mathrm{Mg}, \mathrm{Fe}, \mathrm{Zn}$ and $\mathrm{Mn}$ ) were performed by atomic absorption spectroscopy on SpectrAA10 (Varian, Australia), using air acetylene flame and $10 \mathrm{~cm}$ burner.

Sugars and acids content. For determination of sugars and organic acids composition weight sample was dissolved in three fold higher volume of demineralized water, supernatant was separated by centrifugation for 5 minutes at $10.000 \times \mathrm{rpm}$ and aliquot was diluted with two fold higher volume of acetonitrile and kept at $-18^{\circ} \mathrm{C}$ until analysis. Prior to high-performance liquid chromatographic (HPLC) analysis prepared samples were filtered through $0.45-\mu \mathrm{m}$ pore size filters. A HPLC method Agilent 1200 Series LC system (Agilent Technologies Inc., USA) was applied to determine sugars (fructose, glucose and sucrose) and acids (citric, malic and succinic) content in lettuce extracts. For sugars determinations liquid chromatograph was equipped with an evaporative light scattering detector (ELSD) and Zorbax carbohydrate analysis column $4.6 \times 250 \mathrm{~mm}$, $5 \mu \mathrm{m}$ column (Agilent Technologies Inc.). Solvent system of acetonitrile and water $(75: 25, \mathrm{v} / \mathrm{v})$ at a flowrate of $1.1 \mathrm{~mL} \mathrm{~min}^{-1}$ with total running time of 12 minutes was used. Injection was performed automatically with injection volume of $10 \mu \mathrm{L}$.

For organic acids determination liquid chromatograph was equipped with a diode array detector (DAD) and nucleogel sugar $810 \mathrm{H}$ (Macherey-Nagel $\mathrm{GmbH} \& \mathrm{Co}$. KG) column. For elution $5 \mathrm{mmol}$ of sulfuric acid $\left(\mathrm{H}_{2} \mathrm{SO}_{4}\right)$ was used at a flow-rate of $0.6 \mathrm{~mL} \mathrm{~min}^{-1}$ at $65^{\circ} \mathrm{C}$, and total running time was 25 minutes. Peaks were recorded at $210 \mathrm{~nm}$. The injected volume of samples and standards was $5 \mu \mathrm{L}$.

Standard solutions of sugars and organic acids were used for development of calibration curves. Peaks were identified based on retention time comparison, and the concentrations were quantified from developed linear regressions.

Extraction of total extractable phenols was performed according to the procedure proposed by Larrauri et al. (1997) with minor modifications as follows: $2 \mathrm{~g}$ of sample were extracted sequentially with $20 \mathrm{~mL}$ of methanol:water $(50: 50, \mathrm{v}: \mathrm{v})$ and $20 \mathrm{ml}$ of acetone:water (70:30, v:v) at orbital shaker PSU-10i (Boeco, Germany) for 60 minutes each at room temperature. After centrifugation (centrifuge) for 5 minutes at $10.000 \times$ rpm combined supernatants were made up to $50 \mathrm{ml}$ with mixture water:acetone:methanol (40:35:25, v:v:v).

Total phenol content was determined according to Folin-Ciocalteu method. In brief: to $1 \mathrm{~mL}$ of extract $7 \mathrm{~mL}$ of water and $0.5 \mathrm{ml}$ of Folin-Ciocalteu reagent diluted with water $(1: 1, \mathrm{v}: \mathrm{v})$ were added, after 10 minutes of equilibration $1.5 \mathrm{~mL}$ of sodium carbonate $\left(\mathrm{Na}_{2} \mathrm{CO}_{3}\right)$ solution $(20 \%, \mathrm{w} / \mathrm{v})$ was added. After 30 minutes absorbance was recorded at $730 \mathrm{~nm}$ with a spectrometer Cintra 303 (GBC Scientific Equipment). The results were calculated from the calibration obtained using gallic acid as the reference standard.
Statistical analysis. Significance of effect of different shade nets on lettuce was determined by analysis of variance (ANOVA) followed by Duncan's multiple range test. Software STATISTICA 13 (Dell Inc., 2016) was used for all calculations.

\section{Results and discussion}

Firstly, the effects of different colour shade nets on harvested lettuce composition in comparison to open field production during the summer season depending on the leaf position in the lettuce head are presented. Besides the obvious fact that the chlorophyll content is higher in external than in the internal leaves the tendencies related to the influence of shading nets application on chlorophyll content are also noted. In lettuce leaves exposed to the light in comparison to non-shaded lettuce total chlorophyll content was significantly higher only in the case of lettuce grown under the blue shading net. Under red and black shading nets total chlorophyll content in the leaves exposed to the light was at the same level as in the non-shaded plant, while under the pearl shade net exposed lettuce leaves exhibited significantly lower total chlorophyll content in comparison to all other treatments. However, internal leaves of the lettuce grown under the pearl shade net exhibited the highest total chlorophyll content although the difference was not statistically significant in comparison to non-shaded plants and the plants grown under the blue shading net. Total chlorophyll content in internal leaves of lettuce grown under pearl nets was significantly higher in comparison to the internal leaves of lettuce grown under red and black shade nets (Table 1). Moreover, pearl net exhibited the most expressed and diverse effects on chlorophyll content and composition indicating that all factors: shading, spectra alteration and light scattering play a role in resulting chlorophyll content, composition and distribution in lettuce heads.

Internal leaves in plants from open field and all shading treatments had higher sugars content. Soluble sugars were affected significantly also by the shading treatments. Soluble sugars content in external leaves of non-shaded lettuce is higher in comparison to all shading treatments. The results Agüero et al. (2011) showed that an increase in the length of the light period and temperature enhanced the concentration of soluble sugars, the light period having more pronounced influence in this respect than the temperature. Among the three analysed sugars the level of fructose was higher than that of glucose and sucrose.

Shading treatments affect organic acids content in butter lettuce from summer production. Thus, both external and internal non-shaded lettuce leaves contain more organic acids than leaves from shade plants. Internal leaves contain more organic acids content than external (light-exposed) leaves from all shaded treatments and non-shaded plants. Among the three organic acids level of malic acid was higher than that of succinic and citric acids (Table 1). Content of malic and succinic acids is higher in internal leaves, while citric acid in internal leaves was not detected. Leaves from non-shaded plants had higher content of sugars and acids in comparison to shaded plants. Significantly higher total phenol content was recorded in external and internal leaves when lettuce was grown under open field production. Obtained results indicate that application of shading and different colour 
shading nets affect the composition of external, lightexposed leaves to higher extent compared to internal leaves (Table 1).

The differences in composition of external and internal leaves are the main source of variability, while the shading process and particularly the shading net colours have minor influence. Stagnari et al. (2015) reported that increased shading reduces total phenols content and total antioxidant activity in lettuce, while Hipol and DionisioSese (2014) noted in three cultivars of red lettuce that the increase of light significantly increases total phenols content. Regarding the mineral concentrations in lettuce leaves, we recorded the highest values for $\mathrm{K}$ (in external leaves - 777.86, in internal leaves $-338.02 \mathrm{mg} 100 \mathrm{~g}^{-1}$ fresh weight $(\mathrm{FW})$ ) and $\mathrm{Ca}$ (in external - 142.24, in internal - $28.47 \mathrm{mg} 100 \mathrm{~g}^{-1} \mathrm{FW}$ ), and the lowest for $\mathrm{Zn}$

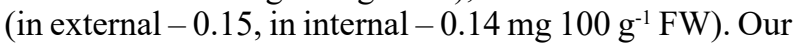
results considering the mineral content are in agreement with those observed by Stagnari et al. (2015).

Table 1. Effects of coloured shade nets on chlorophyll, soluble sugars, organic acids and total phenols content (mg $100 \mathrm{~g}^{-1}$ fresh weight) in external and internal butter lettuce leaves at harvest

\begin{tabular}{|c|c|c|c|c|c|c|c|c|}
\hline \multirow{2}{*}{$\begin{array}{c}\text { Colour } \\
\text { nets }\end{array}$} & \multirow{2}{*}{ Chlorophyll } & \multicolumn{3}{|c|}{ Soluble sugars } & \multicolumn{3}{|c|}{ Organic acids } & \multirow{2}{*}{ Total phenols } \\
\hline & & fructose & glucose & sucrose & malic & citric & succinic & \\
\hline \multicolumn{9}{|c|}{ External leaves } \\
\hline Red & $40.99 \mathrm{~b}$ & $167 \mathrm{~g}$ & $35 \mathrm{~h}$ & $134 \mathrm{fg}$ & $234 \mathrm{~d}$ & $46 \mathrm{~b}$ & $81 \mathrm{i}$ & $46.85 \mathrm{c}$ \\
\hline Pearl & $35.21 \mathrm{c}$ & $208 \mathrm{e}$ & $72 \mathrm{~g}$ & $130 \mathrm{~g}$ & $233 \mathrm{~d}$ & $43 \mathrm{~b}$ & $191 \mathrm{e}$ & $55.78 \mathrm{~b}$ \\
\hline Blue & $51.94 \mathrm{a}$ & $189 \mathrm{f}$ & $68 \mathrm{~g}$ & $123 \mathrm{~h}$ & $215 \mathrm{e}$ & $40 \mathrm{~b}$ & $120 \mathrm{~g}$ & $54.13 \mathrm{~b}$ \\
\hline Black & $38.84 \mathrm{~b}$ & $205 \mathrm{e}$ & $68 \mathrm{~g}$ & $136 \mathrm{f}$ & $171 \mathrm{f}$ & $38 \mathrm{~b}$ & $110 \mathrm{~h}$ & $56.42 \mathrm{~b}$ \\
\hline Control & $41.46 \mathrm{~b}$ & $213 \mathrm{e}$ & $105 \mathrm{f}$ & $150 \mathrm{e}$ & $286 \mathrm{~b}$ & $67 \mathrm{a}$ & $142 \mathrm{f}$ & $87.90 \mathrm{a}$ \\
\hline \multicolumn{9}{|c|}{ Internal leaves } \\
\hline Red & $3.39 \mathrm{e}$ & $404 \mathrm{~b}$ & $328 \mathrm{~b}$ & $157 \mathrm{~d}$ & $278 \mathrm{~b}$ & nd & $305 \mathrm{c}$ & $46.00 \mathrm{c}$ \\
\hline Pearl & $5.75 \mathrm{~d}$ & $413 b$ & $314 c$ & $172 \mathrm{c}$ & $215 \mathrm{e}$ & nd & $302 c$ & $43.56 \mathrm{c}$ \\
\hline Blue & $3.75 \mathrm{de}$ & $340 \mathrm{~d}$ & $215 \mathrm{e}$ & $180 \mathrm{~b}$ & $256 \mathrm{c}$ & nd & $385 \mathrm{a}$ & $43.68 \mathrm{c}$ \\
\hline Black & $2.38 \mathrm{e}$ & $390 \mathrm{c}$ & $265 \mathrm{~d}$ & $157 \mathrm{~d}$ & $284 \mathrm{~b}$ & nd & $324 \mathrm{~b}$ & $52.77 \mathrm{~b}$ \\
\hline Control & $4.59 \mathrm{de}$ & $444 \mathrm{a}$ & $384 \mathrm{a}$ & $256 \mathrm{a}$ & $330 \mathrm{a}$ & nd & $325 \mathrm{~b}$ & $61.88 \mathrm{ab}$ \\
\hline
\end{tabular}

Control - non-shaded plants; nd - not detected

Both macro and micro element levels are significantly higher in external lettuce leaves compared to internal leaves (Table 2). The most marked difference between external and internal leaves is exhibited in the case of Fe, with 4-6 times higher Fe content in lightexposed external leaves.

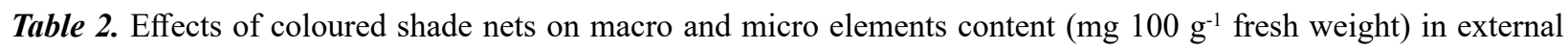
and internal butter lettuce leaves at harvest

\begin{tabular}{|c|c|c|c|c|c|c|}
\hline \multirow{2}{*}{$\begin{array}{l}\text { Colour } \\
\text { nets }\end{array}$} & $\mathrm{K}$ & $\mathrm{Ca}$ & $\mathrm{Mg}$ & $\mathrm{Fe}$ & $\mathrm{Mn}$ & $\mathrm{Zn}$ \\
\hline & \multicolumn{6}{|c|}{ External leaves } \\
\hline Red & $696.59 \mathrm{~b}$ & $92.42 \mathrm{~b}$ & $19.59 \mathrm{~b}$ & $2.44 \mathrm{~b}$ & $0.34 \mathrm{~b}$ & $0.14 \mathrm{cde}$ \\
\hline Pearl & $560.75 \mathrm{c}$ & $60.74 \mathrm{e}$ & $13.56 \mathrm{~d}$ & $2.41 \mathrm{~b}$ & $0.27 \mathrm{c}$ & $0.21 \mathrm{a}$ \\
\hline Blue & $590.74 \mathrm{c}$ & $78.96 \mathrm{c}$ & $18.93 \mathrm{~b}$ & $2.24 \mathrm{~b}$ & $0.25 \mathrm{c}$ & $0.17 \mathrm{~b}$ \\
\hline Black & $579.60 \mathrm{c}$ & $70.77 \mathrm{~d}$ & $15.44 \mathrm{c}$ & $1.67 \mathrm{c}$ & $0.26 \mathrm{c}$ & $0.16 \mathrm{bc}$ \\
\hline \multirow[t]{2}{*}{ Control* } & $777.86 \mathrm{a}$ & $142.24 \mathrm{a}$ & $26.79 \mathrm{a}$ & $5.40 \mathrm{a}$ & $0.43 \mathrm{a}$ & $0.15 \mathrm{bcd}$ \\
\hline & \multicolumn{6}{|c|}{ Internal leaves } \\
\hline Red & $263.65 \mathrm{e}$ & $24.81 \mathrm{fg}$ & $7.46 \mathrm{e}$ & $0.35 \mathrm{e}$ & $<0.02$ & $0.11 \mathrm{f}$ \\
\hline Pearl & $342.54 \mathrm{~d}$ & $21.54 \mathrm{fg}$ & $7.70 \mathrm{e}$ & $0.39 \mathrm{e}$ & $<0.02$ & $0.13 \mathrm{def}$ \\
\hline Blue & $338.29 \mathrm{~d}$ & $21.97 \mathrm{fg}$ & $8.01 \mathrm{e}$ & $0.52 \mathrm{e}$ & $<0.02$ & 0.12 ef \\
\hline Black & $313.12 \mathrm{~d}$ & $19.75 \mathrm{~g}$ & $7.34 \mathrm{e}$ & $0.28 \mathrm{e}$ & $<0.02$ & $0.13 \mathrm{de}$ \\
\hline Control & $338.02 \mathrm{~d}$ & $28.47 \mathrm{f}$ & $8.37 \mathrm{e}$ & $0.81 \mathrm{~d}$ & $0.12 \mathrm{~d}$ & 0.14 cde \\
\hline
\end{tabular}

* - non-shaded plants

For other analysed elements the content in internal leaves was two to three times lower than in the external leaves. The least expressed difference between external an internal lettuce head parts is noted in the case of $\mathrm{Zn}$.

In external leaves of non-shaded lettuce the content of micro and macro elements, except for $\mathrm{Zn}$, is significantly higher in comparison to all shading treatments. However, the differences in mineral content in internal leaves between non-shaded and shaded plants is not significant except for $\mathrm{Fe}$ that has significantly higher content also in internal leaves of non-shaded lettuce (Table 2).

Highly significant influence of changes in photosynthetically active radiation on $\mathrm{Ca}, \mathrm{P}, \mathrm{Mg}, \mathrm{K}, \mathrm{Mn}$, $\mathrm{Zn}$ and $\mathrm{Fe}$ content was also observed by Stagnari et al.
(2015), but the reported trends from this investigation are opposite to our findings. Namely according to Stagnari et al. (2015), reduction of photosynthetically active radiation increased the content of $\mathrm{K}, \mathrm{Ca}, \mathrm{Mg}, \mathrm{P}, \mathrm{Fe}, \mathrm{Mn}$ and $\mathrm{Zn}$. However, the content of minerals in leaves of lettuce depends on maturity and soil properties (Pinto et al., 2014). According to Mampholo et al. (2016), who reported significant differences in $\mathrm{N}, \mathrm{Mg}, \mathrm{Ca}, \mathrm{P}, \mathrm{K}$ and $\mathrm{Zn}$ content among 16 lettuce cultivars grown under the same conditions, mineral content highly depends also on lettuce cultivar.

In the second part of our considerations we presented the effects of light modification by shade nets and leaf position (external compared to internal) on nutritional composition during the storage. 
In general, during the lettuce storage, external leaves have more water available to be used in degradation reactions, and thus are more perishable and have shorter shelf life in comparison to the internal leaves. Additionally, external leaves are more perishable than internal ones because of their direct exposure to environmental conditions. During lettuce storage, water status index evolution differs from external to internal zone, including initial values of each zone as well as in their evolution during storage under optimal conditions. Consequently, whole lettuce heads show different shelf life among zones under optimal storage condition and before whole lettuce heads trading, it is common practice to remove the external leaves as storage advances. However, there are findings showing that lettuce grown under pearl nets had the lowest weight loss after postharvest storage. Therefore, factors other than major environmental exposure of external leaves may be responsible for lettuce quality loss (Ntsoane, 2015).

Our findings related to initial moisture content in external and internal leaves, and its changes after 10 and 20 days of storage under high relative humidity and low temperature conditions are in line with these statements (Fig. 1). At the harvest time the main difference in moisture content is related to significantly lower moisture content in both external and internal leaves of lettuce grown without shading in comparison to all shading treatments. Additionally, during the storage non-shaded lettuce suffered much higher water losses in comparison to the shaded lettuces. Finally, moisture content loss is more expressed in external leaves, while in internal leaves moisture content remained almost at the same level during the whole storage period. However, during the short storage period the lettuce grown under the pearl net was characterized by the lowest water loss in external leaves, but during the longer storage this advantage was annulled.

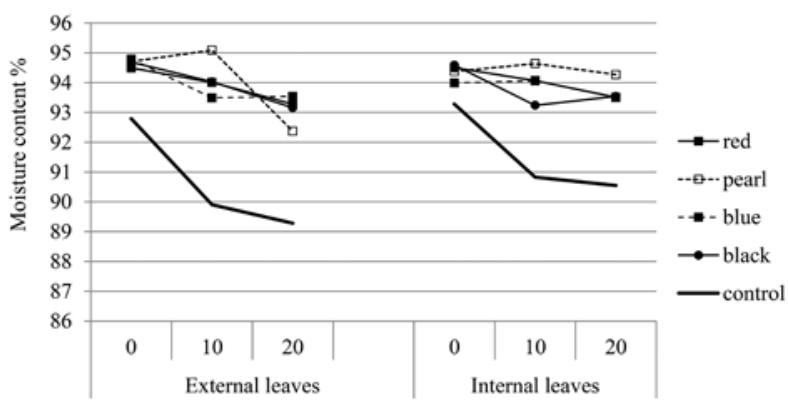

Days at $0^{\circ} \mathrm{C}, 95 \%$ relative humidity

Figure 1. Changes in moisture content during postharvest storage in external and internal leaves of butter lettuce grown under different colour shade nets

Soluble solid content (SSC) $\left({ }^{\circ} \mathrm{Brix}\right)$ is an important quality criterion in lettuce. Based on soluble sugar analysis, the initial SSC was affected significantly by the shading treatments lowering the initial SSC. Although lettuce contains low to moderate level of soluble solid matter $\left({ }^{\circ}\right.$ Brix $)$, the increase in sugar content due to metabolic processes in lettuce leaves under the low light conditions storage is one of the phenomena limiting the shelf life of lettuce.

Our results point out that the production of lettuce under the shade nets contributes to high extent to the sugar metabolism processes in the stored lettuce heads (Fig. 2). The increase of sugar content in both external and internal leaves of non-shaded plants is rapid and permanent during 20 days of lettuce storage, while in all shaded plants the increase of sugar content is much less expressed. In external leaves sugar content of shaded lettuce leaves increases slowly during the first 10 days of storage and afterwards remains almost at the same level. In the internal leaves there is almost no change in sugar content during the first period of storage, and afterwards the sugar content increases, but the increase is much less expressed than in the non-shaded plants. Among different net colours the most rapid sugar content increase was recorded for the plants grown under the blue shading nets indicating the most intensive sugar metabolism in the postharvest period when this production conditions are used.

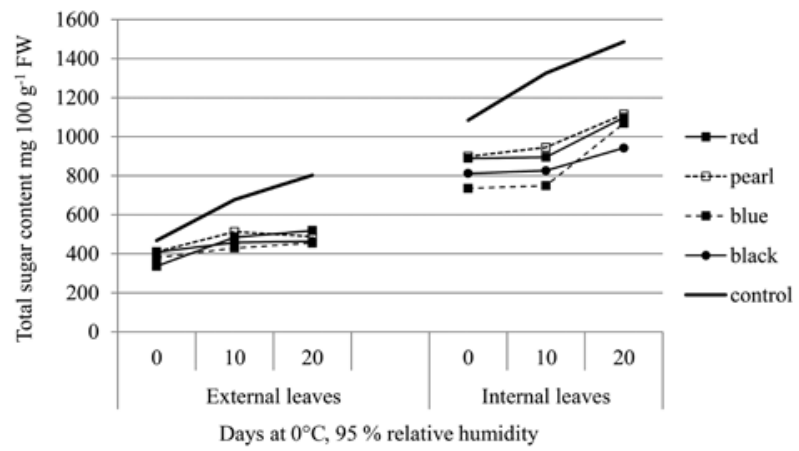

Figure 2. Changes of total sugar content during postharvest storage in external and internal leaves of butter lettuce grown under different colour shade nets

Lettuce is also characterized by low titratable acidity (TA). When comparing total acids content present in lettuce plants at harvest and after storage, the tendency that total acids content increases during storage time was observed (Fig. 3). The most rapid increase in total organic acids content was noted in the external leaves of non-shaded plants. However, the internal leaves of nonshaded lettuce were not characterized by rapid increase of total organic acids content. Changes in total organic acids content in shaded lettuce leaves were also not highly expressed, but slight differences among shading nets of different colours could be noted. The main observation is that total organic acids content in both internal and external leaves of lettuce grown under the red shading net demonstrated almost no change during the whole storage period, while under the other net colours the increase of total organic acids content was slight and similar regardless of net colour and leaf position in the lettuce head.

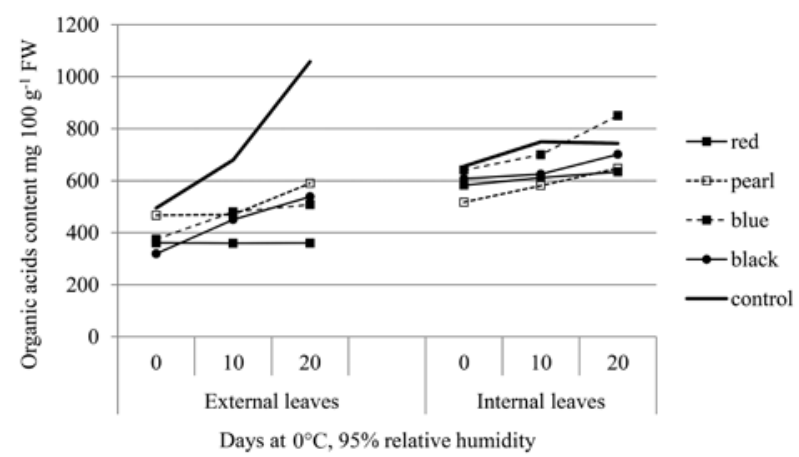

Figure 3. Changes of total organic acids content during postharvest storage in external and internal leaves of butter lettuce grown under different colour shade nets 
Differences in changes of total soluble sugar and total organic acids content in lettuce affected the SSC:TA ratio. This fact might lead to bitter taste, an undesirable characteristic for the consumer, which is related to accumulation of substances such as acids, phenols and alcohol from deteriorating processes (Silva et al., 2017), observed after storage, that could be attributed to acidity increase that was particularly expressed in external leaves of non-shaded lettuce. Ntsoane et al. (2016) stated that SSC:TA ratio was higher in lettuce produced under yellow and pearl nets compared with lettuce produced under red and black nets. In our investigation, higher total soluble sugars and total organic acids content was observed in internal leaves (1.14-1.72 after harvest and 1.25-1.99 after 20 days of storage) resulting in their mild highly acceptable taste. In external leaves this ratio ranged from 0.97 to 1.28 after the harvest resulting in well-known slightly bitter taste of external leaves. After storage this ratio in external leaves significantly decreased resulting in less acceptable taste for the consumers. The only exception was external leaves of lettuce grown under the red net, in which this ratio increased also in external leaves.

Degradation in chlorophyll pigments, which occurred faster in external leaf tissues of lettuce heads, may play an important role in quality loss. In some studies no statistically significant decrease of chlorophyll contentduring 14 days of storage at $4^{\circ} \mathrm{C}$ was observed (Perucka et al., 2013), while Agüero et al. (2008) reported that the chlorophyll degradation in lettuce occurs predominantly in outer leaves of lettuce, while in middle and inner leaves no significant changes were recorded. Total chlorophyll and carotenoids content did not change during lettuce storage under both temperature $\left(4^{\circ} \mathrm{C}\right.$ and $10^{\circ} \mathrm{C}$, respectively) conditions (Spinardi, Ferrante, 2012). The decrease is more pronounced at higher temperatures and chlorophyll degradation occurs predominantly at the beginning of storage (first $3 \mathrm{~h}$ ), while after initial intense chlorophyll degradation, the pigment degradation rate is significantly lower (Agüero et al., 2011).

Changes of chlorophyll content during the postharvest period in lettuce external and internal leaves are presented in Figure 4. Our findings point out that, regardless of the treatment, there were no significant changes in chlorophyll content during the storage period of 20 days in internal leaves. In external leaves even slight, non-significant increase could be noted, but this effect might be attributed to the decrease of moisture content resulting in relative concentration of chlorophyll in leaves.

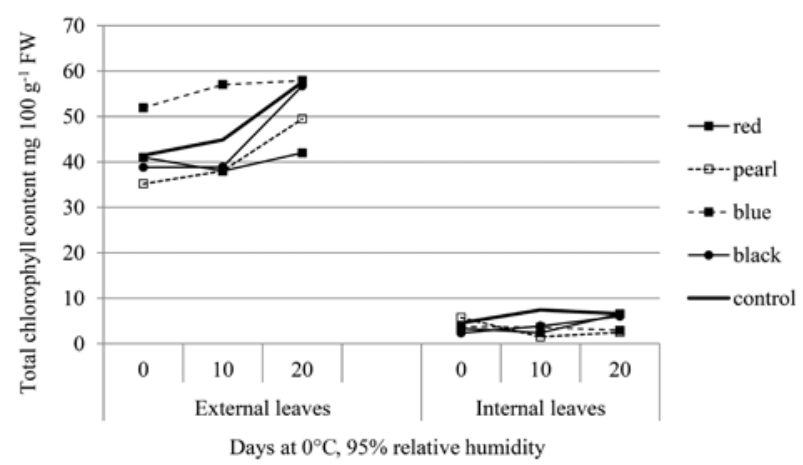

Figure 4. Changes of total chlorophyll content during postharvest storage in external and internal leaves of butter lettuce grown under different colour shade nets
As a response to biotic and abiotic stress plants synthetize antioxidants with phenols being among the most frequent ones (Chalker-Scott, 1999; Rivero et al., 2001; Michalak, 2006). Total phenol content in leaves exposed to the light was $55-85 \%$ higher and in internal leaves $20-45 \%$ higher than in shaded lettuce (Table 1). Total phenols content in non-shaded plants decreased in external leaves during the first storage period, while in internal leaves further increase was noted in this period. In internal leaves, neither significant differences among phenols content in plants grown under red, blue and pearl net nor their significant changes during the postharvest storage were noticed, while in external leaves slight decrease occurred during the first ten days of cold storage. However, the finding reported by Mashabela et al. (2015) demonstrated that internal leaves of lettuce grown under the black shading net were characterized by significantly higher total phenols content in comparison to all other net colours. These findings point out that higher spectral red:far-red (R:FR) ratio under the photoselective pearl net would have stimulated the higher biosynthesis of total phenols at harvest and preservation after postharvest storage.

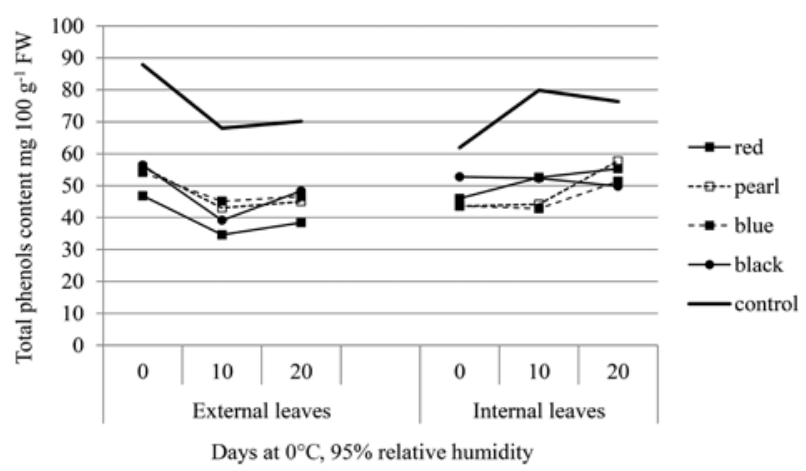

Figure 5. Changes of total phenols content during postharvest storage in external and internal leaves of butter lettuce grown under different colour shade nets

Appropriate storage time and temperature might prevent loss and a decline of total phenols content. According to Ntsoane et al. (2016), phytochemical content was higher at harvest and after postharvest storage in lettuce produced under the black nets. Although lettuce production under the black nets showed higher retention of total phenols after postharvest storage, pearl nets showed less weight loss and higher ascorbic acid content after postharvest storage (Ntsoane et al., 2016).

Further research is needed to analyse the effect of the light spectra modifications on other nutritional properties of lettuce and to optimize both the production as well as the nutritional value of the leaves. The new colour shade technology strategies should be transferred to farmers for production of high commodities at fresh and preservation of postharvest quality of lettuce in order to maintain quality and meet the consumers demand for high nutritional value crops all year round.

\section{Conclusion}

Production and storage of cool-season vegetables like lettuce during the summer months represent a challenge for lettuce growers. Quality parameters of the butter lettuce produced under different colour shade nets were dependent not only on the position of lettuce 
leaves in the head, but were also significantly affected by the shading and duration of the storage. Besides the confirmation that lettuce is characterized by significant content of nutrients, which may be maintained during storage at appropriate temperatures $\left(0^{\circ} \mathrm{C}\right)$ and high relative humidity $(95 \%)$, this study pointed out that the application of shading nets in production of lettuce in the summer period can affect both, the composition of harvested lettuce regarding both, internal and external leaves, as well as the changes in their composition in the postharvest period during the storage under optimal conditions.

Lettuce produced without shading in the summer period, due to higher content of phenols as well as higher content of organic acids such as malic and particularly citric, and succinic acids might have bitter taste, and thus be less acceptable for the consumers. Due to less expressed stress factors, lettuce produced under the shading nets had lower phenols content, and in spite of lower expectations related to antioxidative potential, would be more acceptable for consumers in terms of taste.

In the postharvest period the main differences were related to water and sugars metabolism. During the storage, non-shaded lettuce suffered much higher water losses in comparison to the shaded lettuces. In all shaded plants the increase of sugars content was much less expressed than in the non-shaded plants pointing out at the possibilities of retention of quality during longer storage period.

Further investigations using colour shade nets should be performed to ensure the use of effective strategies for managing plant growth during summer season and for improving lettuce quality at harvest and maintaining quality during the storage.

\section{Acknowledgements}

This study, which was part of the projects TR-31027 and III46001, was financially supported by the Ministry of Education, Science and Technological Development of the Republic of Serbia.

Received 10012018 Accepted 01082018

\section{References}

1. Agüero M. V., Barg M. V., Yommi A., Camelo A., Roura S. I. 2008. Postharvest changes in water status and chlorophyll content of lettuce (Lactuca sativa L.) and their relationship with overall visual quality. Journal of Food Science, 73 (1): S47-S55. https://doi.org/10.1111/j.1750-3841.2007.00604.x

2. Agüero M. V., Ponce A. G., Bevilacqua A., Roura S. I. 2011. Postharvest quality losses of butter lettuce as affected by leaf age and temperature. Fresh Produce, 5 (1): 20-25.

3. Arthurs S. P., Stamps R. H., Giglia F. F. 2013. Environmental modification inside photoselective shade houses. HortScience, 48 (8): 975-979.

4. Cantwell M., Suslow T. 2002. Lettuce, crisphead: recommendations for maintaining postharvest quality. http://ucanr.edu/sites/Postharvest_Technology_Center_ Commodity Resources/Fact Sheets/Datastores Vegetables_English/?uid $=19 \& d s=\overline{7} 99$

5. Castellano S., Scarascia Mugnozza G., Russo G., Briassoulis D., Mistrionis A., Hemming S., Waaijenberg D. 2008. Plastic nets in agriculture: a general review of types and applications. Applied Engineering in Agriculture, 24: 799-808. https://doi.org/10.13031/2013.25368
6. Chalker-Scott L. 1999. Environmental significance of anthocyanins in plant stress responses. Photochemistry and Photobiology, 70 (1): 1-9.

https://doi.org/10.1111/j.1751-1097.1999.tb01944.x

7. Costache M. A., Campeanu G., Neata G. 2012. Studies concerning the extraction of chlorophyll and total carotenoids from vegetables. Romanian Biotechnological Letters, 17 (5): 7703-7708.

8. Degl'Innoocenti E., Pardossi A., Tattini M., Guidi L. 2008. Phenolic compounds and antioxidant power in minimally processed salad. Journal of Food Biochemistry, 32 (5): 642-653.

https://doi.org/10.1111/j.1745-4514.2008.00188.x

9. Demotes-Mainard S., Péron T., Corot A., Bertheloot J., Gourrierec J., Le Travier S., Sakr S. 2016. Plant responses to red and far-red lights, applications in horticulture. Environmental and Experimental Botany, 121: 4-21. https://doi.org/10.1016/j.envexpbot.2015.05.010

10. Dufault R. J., Ward B., Hassell R. L. 2009. Dynamic relationships between field temperatures and romaine lettuce yield and head quality. Scientia Horticulturae, 120: 452-459.

https://doi.org/10.1016/j.scienta.2009.01.002

11. Hipol R. L. B., Dionisio-Sese M. L. 2014. Impact of light variation on the antioxidant properties of red lettuce. Electronic Journal of Biology, 10 (2): 28-34.

12. Ilić S. Z., Fallik E. 2017. Light quality manipulation improves vegetables quality at harvest and postharvest: a review. Environment Experimental Botany, 139: 79-90. https://doi.org/10.1016/j.envexpbot.2017.04.006

13. Ilić S. Z., Milenković L., Stanojević L., Cvetković D., Fallik E. 2012. Effects of the modification of light intensity by color shade nets on yield and quality of tomato fruits. Scientia Horticulturae, 139: 90-95. https://doi.org/10.1016/j.scienta.2012.03.009

14. Ilić S. Z., Milenković L., Šunić L., Fallik E. 2015. Effect of coloured shade-nets on plant leaf parameters and tomato fruit quality. Journal of the Science of Food and Agriculture, 95 (13): 2660-2667. https://doi.org/10.1002/jsfa.7000

15. Ilić S. Z., Milenković L., Dimitrijević A., Stanojević L., Cvetković D., Kevrešan Ž., Fallik E., Mastilović J. 2017 (a). Light quality manipulation by color nets improve quality of lettuce from summer production. Scientia Horticulturae, 226: 389-397. https://doi.org/10.1016/j.scienta.2017.09.009

16. Ilić S. Z., Milenković L., Šunić L., Fallik E. 2017 (b). Effect of shading by colour nets on plant development, yield and fruit quality of sweet pepper grown under plastic tunnels and open field. Zemdirbyste-Agriculture, 104 (1): 53-62. https://doi.org/10.13080/z-a.2017.104.008

17. Kapoulas N., Koukounaras A., Ilić S. Z. 2017. Nutritional quality of lettuce and onion as companion plants from organic and conventional production in north Greece. Scientia Horticultuare, 219: 310-318. https://doi.org/10.1016/j.scienta.2017.03.027

18. Kim M. J., Moon Y., Tou J. C., Mou B., Waterland N. L. 2016. Nutritional value, bioactive compounds and health benefits of lettuce (Lactuca sativa L.). Journal of Food Composition and Analysis, 49: 19-34. https://doi.org/10.1016/j.jfca.2016.03.004

19. Kosma C., Triantafyllidis V., Papasavvas A., Salahas G., Patakas A. 2013. Yield and nutritional quality of greenhouse lettuce as affected by shading and cultivation season. Emirates Journal of Food and Agriculture, 25 (12): 974-979. https://doi.org/10.9755/ejfa.v25i12.16738

20. Larrauri J. A., Rupérez P., Saura-Calixto F. 1997. Mango peel fibers with antioxidant activity. Zeitschrift für Lebensmittel-Untersuchung und Forschung A, 205: 39-42.

21. Mampholo B. M., Maboko M. M., Soundy P., Sivakumar D. 2016. Phytochemicals and overall quality of leafy lettuce (Lactuca sativa L.) varieties grown in closed hydroponic system. Journal of Food Quality, 39 (6): 805-815. https://doi.org/10.1111/jfq.12234 
22. Mashabela M. N., Selahle K. M., Soundy P., Crosby K. M., Sivakumar D. 2015. Bioactive compounds and fruit quality of green sweet pepper grown under different colored shade netting during postharvest storage. Journal of Food Science, 16: 2612-2618. https://doi.org/10.1111/1750-3841.1310 $\underline{3}$

23. Michalak A. 2006. Phenolic compounds and their antioxidant activity in plants growing under heavy metal stress: review. Polish Journal of Environmental Studies, 15 (4): 523-530

24. Milenković L., Ilic S. Z., Đurovka M., Kapoulas N., Mirecki N., Fallik E. 2012. Yield and pepper quality as affected by light intensity using colour shade nets. Agriculture and Forestry, 58 (1): 19-23.

25. Ntsoane M. L. 2015. Effect of photo-selective nettings on plant growth, quality at harvest and after postharvest storage in lettuce varieties: MSc thesis. Tshwane University of Technology, Pretoria, South Africa.

26. Ntsoane L. L. M., Soundy P., Jifon J., Sivakumar D. 2016. Variety-specific responses of lettuce grown under the different-coloured shade nets on phytochemical quality after postharvest storage. The Journal of Horticultural Science and Biotechnology, 91 (5): 520-528. https://doi.org/10.1080/14620316.2016.1178080

27. Perucka I., Olszówka K., Chilczuk B. 2013. Changes in the chlorophyll content in stored lettuce Lactuca sativa L. after pre-harvest foliar application of $\mathrm{CaCl}_{2}$. Acta Agrobotanica, 66 (4): 137-142. https://doi.org/10.5586/aa.2013.060

28. Pinto E., Almeida A. A., Aguiar A. A., Ferreira I. M. 2014. Changes in macrominerals, trace elements and pigments content during lettuce (Lactuca sativa $\mathrm{L}$.) growth: influence of soil composition. Food Chemistry, 152: 603-611. https://doi.org/10.1016/j.foodchem.2013.12.023

29. Rivero R. M., Ruiz J. M., Garcia P. C., Lopez-Lefebre L. R., Sánchez E., Romero L. 2001. Resistance to cold and heat stress: accumulation of phenolic compounds in tomato and watermelon plants. Plant Science, 160 (2): 315-321. https://doi.org/10.1016/S0168-9452(00)00395-2
30. Rouphael Y., Cardarelli M., Bassal A., Leonardi C., Giuffrida F., Colla G. 2012. Vegetable quality as affected by genetic, agronomic and environmental factors. Journal of Food and Agriculture Environment, 10: 680-688.

31. Selahle M. K., Sivakumar D., Soundy P. 2014. Effect of photo-selective nettings on postharvest quality and bioactive compounds in selected tomato cultivars. Journal of Science Food and Agriculture, 94: 2187-2195.

32. Shahak Y., Ratner K., Zur N., Offir Y., Matan E., Yehezkel H., Messika Y., Posalski I., Ben-Yakir D. 2009. Photoselective netting: an emerging approach in protected agriculture. Acta Horticulturae, 807: 79-84. https://doi.org/10.17660/ActaHortic.2009.807.7

33. Silva D. S. O., Rocha R. H. C., Nóbrega J. S., Dias G. A., Lima J. F., Guedes W. A. 2017. Post-harvest quality of lettuce cv. Elba in relation to Spirulina platensis foliar applications. Cientifica Jaboticabal, 45 (2): 162-168. https://doi.org/10.15361/1984-5529.2017v45n2p162-168

34. Siomos A. S., Papadopoulou P. P., Dogras C. C., Vasiliadis E., Dosas A., Georgiou N. 2002. Lettuce composition as affected by genotype and leaf position. Acta Horticulturae, 579: 635-639. https://doi.org/10.17660/ActaHortic.2002.579.112

35. Spinardi A., Ferrante A. 2012. Effect of storage temperature on quality changes of minimally processed baby lettuce. Journal of Food, Agriculture and Environment, 10: 38-42.

36. Stagnari F., Galieni A., Pisante M. 2015. Shading and nitrogen management affect quality, safety and yield of greenhouse-grown leaf lettuce. Scientia Horticulturae, 192: 70-79.

https://doi.org/10.1016/j.scienta.2015.05.003

ISSN 1392-3196 / e-ISSN 2335-8947

Zemdirbyste-Agriculture, vol. 106, No. 1 (2019), p. 65-72

DOI 10.13080/z-a.2019.106.009

\title{
Šviesos modifikacijos įtaka gūžinių salotų kokybei: išorinių ir vidinių lapų skirtumai
}

\author{
J. Mastilović1 ${ }^{2}$ Ž. Kevrešan ${ }^{1}$, A. Jakšić ${ }^{1}$, I. Milovanović ${ }^{1}$, R. Trajkovic ${ }^{2}$, M. Stanković \\ L. Milenković ${ }^{3}$ Z. S. Ilić \\ ${ }^{1}$ Novi Sad universiteto Maisto technologijos institutas, Serbija \\ ${ }^{2}$ Prištinos universiteto Gamtos mokslų ir matematikos fakultetas, Serbija \\ ${ }^{3}$ Prištinos universiteto Žemès ūkio fakultetas, Serbija
}

\begin{abstract}
Santrauka
Tyrimo metu siekta nustatyti spalvotų (melsvai pilkos, mèlynos, raudonos ir juodos spalvos) pavėsinimo tinklų (su $50 \%$ pavėsio indeksu), palyginus su atviru lauku (neužpavèsintais augalais), itaką veislès 'Tizian' gūžinės salotos (Lactuca sativa L. var. capitata) šviežiai nupjautų ir sandèliuotų išorinių bei vidinių lapų kokybei. Palyginus su užpavėsintais, neužpavėsinti augalai turèjo didesni kiekị tirpiujų cukrų ir rūgščių. Derliaus nuėmimo metu reikšmingai didesni chlorofilo, fenolinių junginių ir mikroelementų kiekiai buvo nustatyti išoriniuose lapuose, palyginus su vidiniais. Palyginus su išoriniais šviesos veikiamais lapais, vidiniuose lapuose buvo nustatyti didesni kiekiai tirpiųjų cukrų (gliukozès, fruktozès bei sacharozès) ir organinių rūgščių (obuolių bei gintaro), tačiau citrinos rūgšties buvo nustatyta tik išoriniuose lapuose. Fenolinių junginių suminis kiekis lapuose, paveiktuose šviesos, buvo $55-85 \%$ didesnis nei užpavėsintu augalų lapuose. Gūžinių salotų lapuose laikymo metu suminis tirpiujų cukrų ir rūgščių kiekis intensyviau padidejo neužpavèsintuose lapuose, palyginus su užpavèsintais. Chlorofilo kiekio pokyčiai salotose vyko daugiausia išoriniuose lapuose, o vidiniuose lapuose reikšmingų pokyčių nebuvo nustatyta.
\end{abstract}

